\title{
PROVIDING ENVIRONMENTAL SAFETY IN THE CONDITIONS OF THE DENSE ROAD NETWORK
}

\section{Sheludchenko L. S., Semenyshena R. V.}

\section{INTRODUCTION}

In the Montreal Declaration "People's Right to Safety" (Montreal, Canada, May 15, 2002) the term "safety" is defined as a state in which hazards and conditions leading to physical, psychological or material harm are controlled in order to preserve the health and well being of individuals and the community. That is, the aim is to continuously monitor and develop risk control mechanisms on a continuous basis. However, it should be noted that safety is the result of a complex process where humans interact with their environment, including the physical, social, cultural, technological, political, economic and organizational environments.

The concept of safety is relative, as is its achievement. After all, it will always carry a certain probability, which depends on the characteristics of the object, its complexity, internal relationships and environment. One of the main criteria for safety is the absence of negative dynamics in the development of the system. Practically, safety is a feature of the object to provide no risk. It is a condition in which the risk of injury or damage is reduced to an acceptable level, which is achieved through a set of developed protection systems.

In general, the economic activity of society is characterized by the active use of natural resources, where benefits and dangers are manifested. It doesn't take into account the main environmental priorities, the essence of which is to preserve the quality of environmental objects. However, the abandonment of nature management can also lead to the risk of lost opportunities. Thus, the lack of available resources will lead to a decline in socio-economic development.

Thus, we emphasize that in order to achieve a risk acceptable to society, it is necessary to find an appropriate balance between economic activity and the level of risk that is created by its functioning. 
It should be noted that any activity, and in particular transport infrastructure, entails a certain risk. Its task is not only to anticipate the benefits expected, but also to take into account the potential harm to both human health and the environment. The ability to realize the degree of the risks not only assesses all the dangers, but also requires responsibility for ensuring an appropriate level of safety, including environmental.

Turning potential danger into reality does not lead to an actual disaster, but only turns into a safety risk. Its implementation is carried out only with direct contact with the danger. And this requires at least three conditions:

1) the danger actually works;

2) the object is in the danger zone;

3) the object does not have sufficient protection.

That is why the substantiation of the developments on the ecologically safe functioning of the road network is an urgent scientific and practical problem.

\section{Analysis of environmental hazards related to the road network functioning}

Ukraine's highways are an important link in the country's overall transport system and an important factor in the development of the national economy. In Ukraine most of the roads of international and national importance pass through settlements. Such placement does not meet the requirements for international transport corridors. After all it leads to a restriction of the speed of road transport, which is 2-3 times lower on the roads of Ukraine, than in Western European countries. It should be noted that the development of motorways in general is far behind the pace of motorization of the country. This causes a number of common problems. For example: increase of traffic load on highways, exceedance of permissible load, non-compliance with operational requirements, violation of ecological capacity of territories, pollution of roadside territories with pollutants contained in automobile emissions. To improve the current situation in the concept of creating and operating a national network of international transport corridors in Ukraine, it is envisaged ".. to significantly reduce the negative impact of motor transport on the surrounding territories. This will be achieved through the creation of appropriate environmental conditions on motorways "(quote).

In general, in accordance with the Building Code of Ukraine and the Resolution of the Cabinet of Ministers of Ukraine of August 28, 2013 No. 808 "On approval of the list of activities and objects of increased 
environmental hazard", motorways and individual highway infrastructure is classified as an environmental hazard. Therefore, ensuring a sufficient level of environmental safety in the area of influence of the road network should be carried out by a systematic approach to the development of solutions for the safe development of the motor transport complex within specific territorial conditions 1

This approach will allow not only the economic and transport feasibility but also the environmental component of the project. Its aim is to strive for sustainable economic development of the country and preserving the environment.

\section{Analysis of structural features of forest gas-dust lane roads}

A significant factor in the impact of traffic flows on natural-technogeo-ecosystems (NTGEs) is the spread of pollutants. The main of them are the carbon dioxide and carbon monoxide, nitrogen oxides, hydrocarbons, aldehydes, mineral dust, heavy metals, etc. They have a significant impact on the environment and human health. ${ }^{2}$ Migration and accumulation of pollutants within the NTGEs are due to a number of interrelated factors: weather and climatic conditions, landscape features, eochemical activity of the territory, the presence of protective barriers (including artificially created ones), etc.

One of the types of artificially created protective structures is woodland shrubs. According to the current building codes, they are multifunctional and perform anti-erosion, decorative functions, prevent snow and sand travel of the roadway.

1 Шмандій В.М., Шелудченко Л.С. До питання забезпечення екологічної безпеки територій $з$ розвиненою інфраструктурою автодорожньої мережі. Збірник наукових працьИII-й Всеукраӥнського з'їзу екологів з міжнародною участю. Вінниця: ВНТУ, 2019. С.26; 2 Шелудченко Л.С., Замойський С.М. Управління екологічною безпекою в умовах функціонування автодорожньої мережі. Збірник наукових праць XVII Міжнародної науково-технічної конферениії «Проблеми екологічної безпеки». Кременчук: КрНУ, 2019. C. $92-96$.

2 Внукова Н.В. Вплив автомобільних доріг на екобезпеку комплексу «автомобіль-дорога-середовище». Eastern-European Journal of Enterprise Technologies 5 (3(53)), 2011. С. 43-46; Гриценко А.В., Соловей В.В., Внукова Н.В. Ризики техногенно-екологічного характеру при експлуатації об'єктів автотранспортної інфраструктури. Экология u промышленность, 3,2011. С. 37-40.; Внукова Н.В., Желновач Г.М. Вибір екологічно значимих параметрів автотранспортних систем для оцінки екологічної небезпеки придорожнього простору. Науковий журнал «Екологічна безпека». Кременчук: КрНУ, 2011. № 2/2011 (12). С. 119-123. 
Such multifunctionality of typical structures of forest strips cannot fully ensure the environmentally safe conditions for the functioning of the road network. Similarly, it is not capable of providing reliable protection against mineral dust pollutants produced by road traffic. Important is the development of engineering solutions concerning an urgent scientific and practical task. They relate to the design of forest gas-dust lane structures that will limit the environmental impact of vehicles and provide sufficient environmental protection with a developed road network. But there should be taken into account such factors as: highway category, traffic flow intensity, and weather and landscape features of the territory.

The traditional shape of the transverse profile of a protective forest lane of a highway (in accordance with BRM (Branch Road Methodology) 218.011-98) has the form of a triangle with a more oblique side, turned to the source of emissions, that is, to the carriageway (Fig. 1).

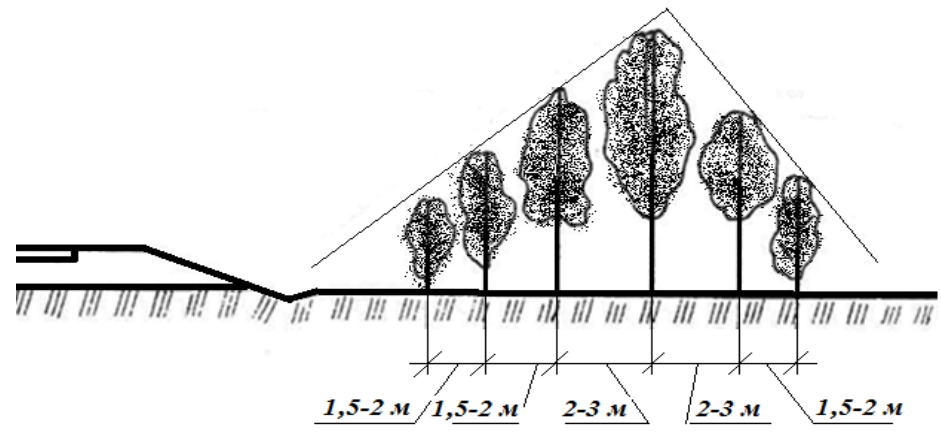

Fig. 1. Cross-section profile of the protective forest belt

The scheme of planting trees and shrubs in the strip is (from left to right):

1st row from the road - low shrub; 2nd row - high shrub;

$3 r d$ row - accompanying tree species; 4 th row - the main tree species;

5 th row-accompanying tree species; 6th row - tall shrub

It should be noted that the design does not provide sufficient protection of the outlying territories from gas and dust emissions in accordance with the determined intensity of traffic flows, which takes into account the category of highway.

The more efficient design of the protective forest strips is the developed variants of the construction of the forest gas-dust-protective strips of the insulating type in the form of artificial linear bilateral 
barriers. These constructions were developed on the basis of fractalinvariant features of the NTGEs landscape, the intensity of traffic flows, and the motor transport capacity of the territory in accordance with the category of roads. Fractal-invariant models of such forest gas-dust lane roads for categories 1a, 1b, 2, 3, 4, 5 of motor roads are shown in Fig. 2. The structure of the protective forest belt is formed by the in-line shrubs and timber planting with corresponding ecological-landscape, functional and morphological properties. At the same time, the above structures of forest gas-dust strips are exclusively part of the engineering infrastructure of the automobile-communication complex. ${ }^{3}$

The structure of the wood-shrub landing of the forest gas-dust protection strip determines the cross-section profile of its structure (hereinafter - the typical structure) in the form of a trapezoid with the angles of lateral sides from the vertical: avers $\alpha \sim 20 \mathrm{O}$ and reverse $\beta \sim$ 30O-50O and height (Fig. 3). The width a of the typical protective forest strip (the lower base of the trapezoidal profile) shall be: for motorways of categories $1 \mathrm{a}$ and $1 \mathrm{~b}$ not less than $32 \mathrm{~m}$, categories $2-\geq 24 \mathrm{~m}$, categories 3 - $\geq 16 \mathrm{~m}$, categories $4-\geq 8 \mathrm{~m}$, categories $5-\geq 4 \mathrm{~m}$.

It is established that the insulating (protective) and renewable (relative to the atmospheric air) properties of typical structures of forest gas-dust protection strips depend on the structural parameters of the strip and its openness. It varies depending on the season, weather and climatic conditions and features of terrain of specific NTGEs.

At the same time, the value of the complex indicator of atmospheric air AQI (Air quality index), (for such ingredients as $\mathrm{CO}, \mathrm{NOx}, \mathrm{SO} 2$ ) on the reverse side of the strip decreases by $\sim 10.7$ times compared to the similar value on its averse side (in the absence of a protective forest belt only $\sim 1.6$ times $)$, and the indicator $\sum \frac{C_{i}}{\Gamma Д \kappa_{\mathrm{i}}} \ll 1\left(C_{i}-\right.$ is the concentration of the relevant pollutant ingredient, and TLV (threshold limit value) is the corresponding value of the maximum permissible pollutant concentration). ${ }^{4}$

3 Шелудченко Л.С. Розроблення конструкцій газо-пилозахисних лісосмуг автодорожньої мережі. Кам'янець-Подільський : В-во ПДАТУ, 2015. 134 с.

${ }^{4}$ Патент України №56323, МПК Е01F15/00 Лісова газо-пилозахисна смуга автомобільної дороги / Л.С. Васик, М.І. Бахмат, Б.А. Шелудченко, О.М. Бахмат, I.А. Шелудченко (Україна). -u201007589; заявлено 10.06.2010; опубл. 10.01.2011, Бюл. № 1.; Шелудченко Л.С. Екологічна безпека ландшафтів природно-територіальних комплексів, які трансформовано автотранспортними мережами. Науковий журнал “Екологічна безпека”. Кременчук : КрНУ, 2017 № 2/2017(24). C. 9-13. 


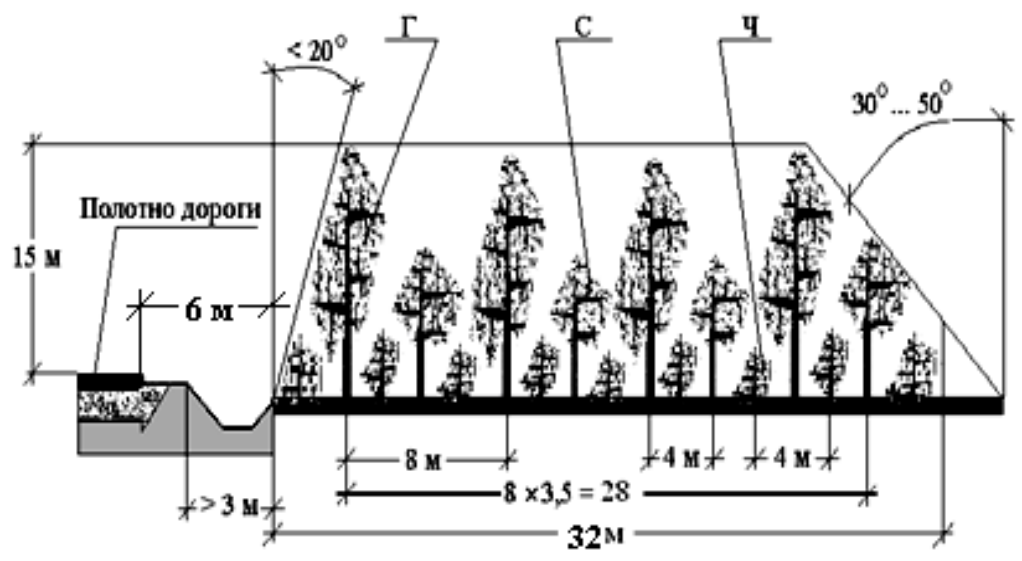

a)

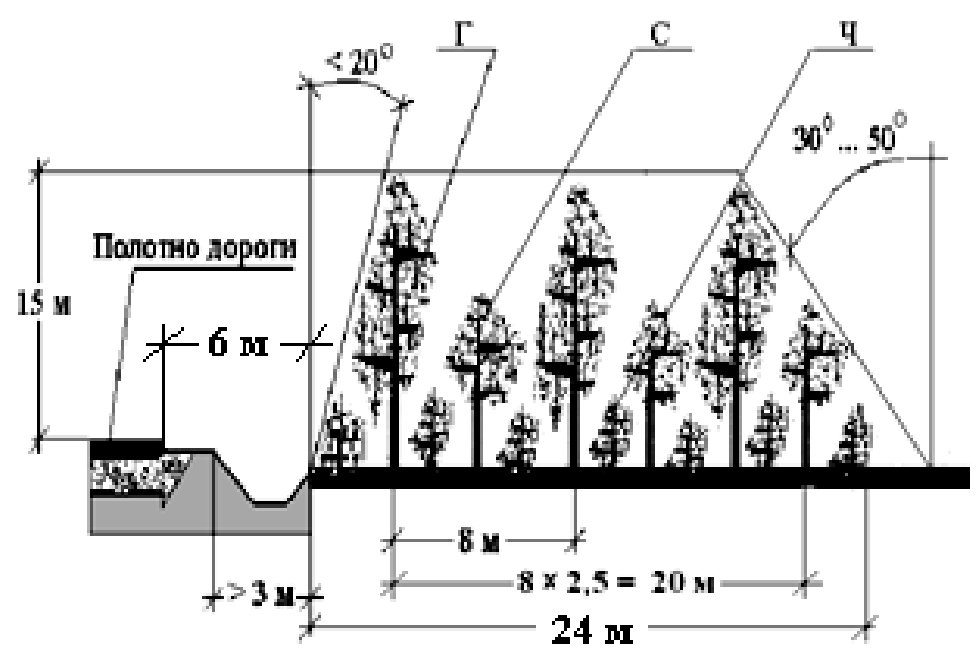

b) 


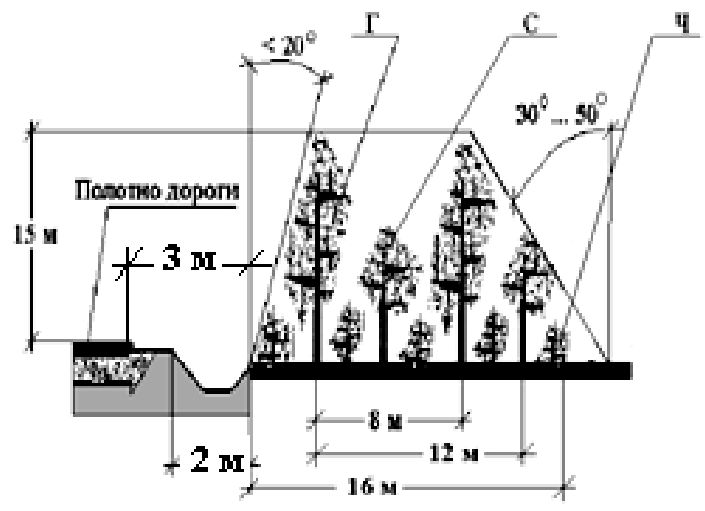

c)

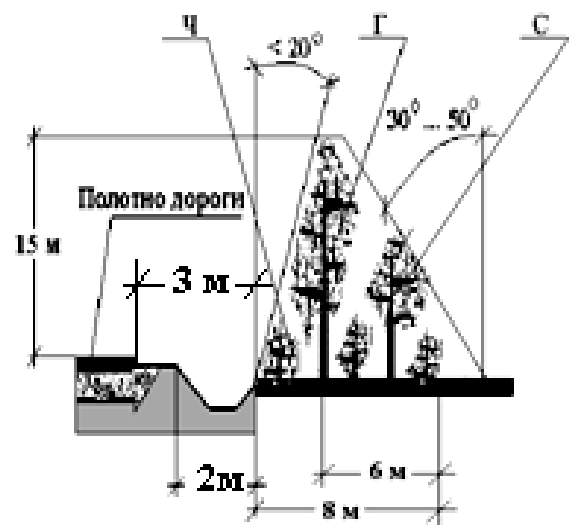

d)

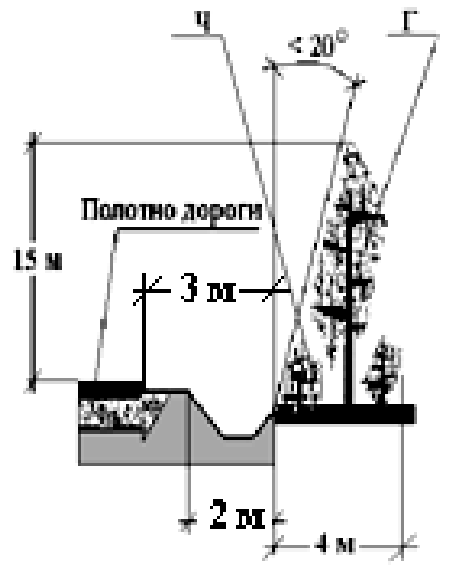

e)

Fig. 2. Fractal-invariant models of forest gas-dust lane strips, depending on the motorway category:

$a$-categories $1 a, 1 b ; b$-category 2 ; $c$-category $3 ; d$-category 4 ; e-category 5;

$G$ - the main tree species; $C$-accompanying tree species; $H$ - shrub

A plan fragment of planting trees and shrubs of a typical construction of the forest gas-dust lane of the highway for categories $1 \mathrm{a}, 1 \mathrm{~b}$ is shown in Fig. 4. However, it should be noted that adhering to the row planting of trees and shrubs, ensuring their level as one of the main conditions, and cenobiotic mosaic structure, which is caused by fractal-invariant 504 
strips, lead to endogenesis and anthropogenic successions, which do phytocenosis of forest strips. Such a feature of the functioning of the forest belt phytocenosis leads to a change in the nature of its protective properties, which is an important problem. ${ }^{5}$

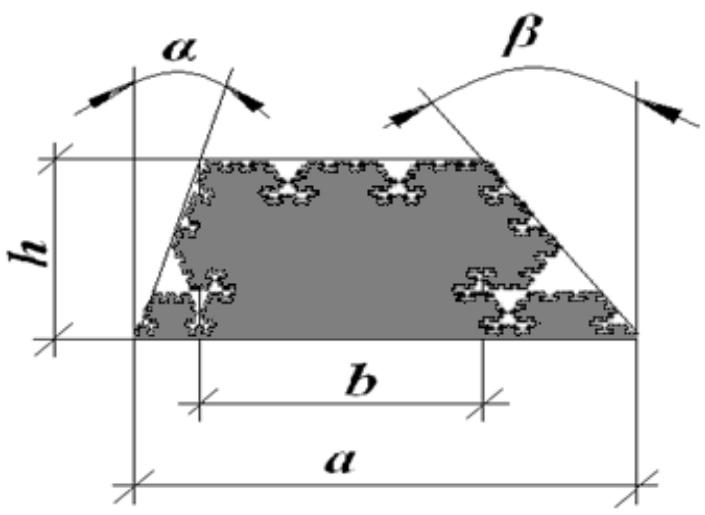

Fig. 3. Geometric parameters of the cross-section profile gas-dust band of wood-shrub type

In addition, we noted that the gas-dusting shrunk lane of a typical highway has high enough characteristics to protect NTGEs from gaseous pollutants (by the ingredients of $\mathrm{CO}, \mathrm{NOx}, \mathrm{SO} 2$ ) and the oxygen recovery rates of the consumed vehicles. However, the protective (insulating) properties of such a forest belt in relation to dust aerosols are due to its aerodynamic characteristics and are insufficient for reliable protection of NTGEs.

Due to this fact, mineral dust is concentrated in the roadway area. And this significantly worsens not only the working conditions of the drivers, but also the modes of operation of vehicles. Reduction of these negative properties of forest gas-dust-protective strips of a typical design is the construction of a protective forest lane of a highway. It is shown in Fig. 5.

5 Шелудченко Л.С., Шелудченко Б.А., Вознюк С.В. Аналітичне обгрунтування параметрів лакунарності лісових газо-пилозахисних смуг автомобільних доріг. Наук.-техн. журнал Екологічна безпека та збалансоване ресурсокористування. Спец. вип. ІФНТУНГ, Івано-Франківськ, 2014. С. 56-60. 


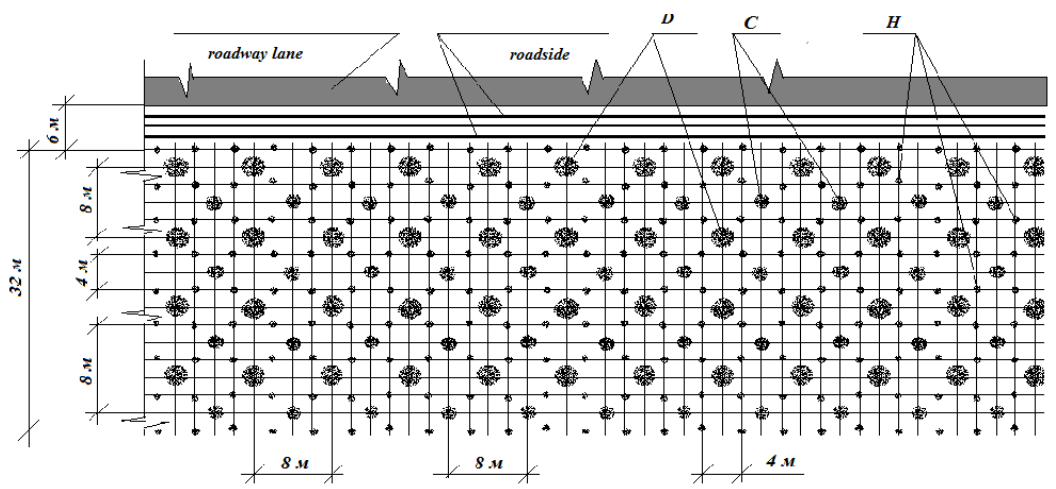

Fig. 4. The scheme of planting trees and shrubs of a typical design of forest gas-dust protection strip of the motorway according to categories 1a, $1 \mathrm{~b}: \mathrm{D}$ is the main tree species, $C$ is the concomitant tree species, $H$ is a shrub

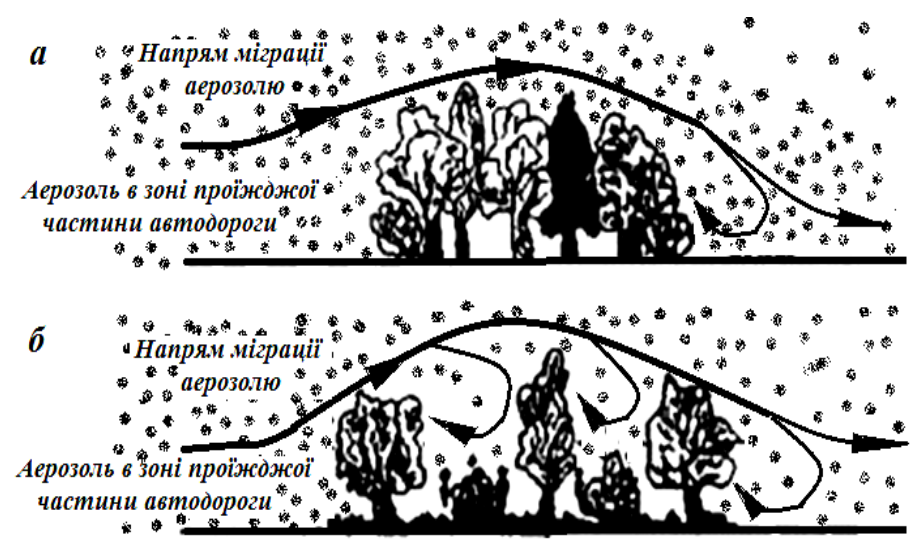

Fig. 5. Derivative design of the protective forest lane of the highway with sparse landing (no accompanying species): $a$-typical construction, $b$-forest belt design with replacement of the accompanying wood species with shrubs

Source: http://www.gosthelp.ru/text/ObzornayainformaciyaAvtom17.html

However, the construction of the forest gas-dust strip, shown in Fig. 5, due to the lineage of planting trees and shrubs, cannot significantly reduce the intensity of migration flows of polluting aerosols. After all the dynamic pressure of the wind flow on the averse 
and reverse sides of the forest belt remains practically fixed. Therefore, the conditions for the gravitational deposition of the dispersed phase of the aerosol are absent.

To reduce the dynamic pressure of liquids or gases (aerosols), we applied the design of a labyrinth seal gap between two (or more) combined surfaces, which is most commonly used in engineering structures (Fig. 6).

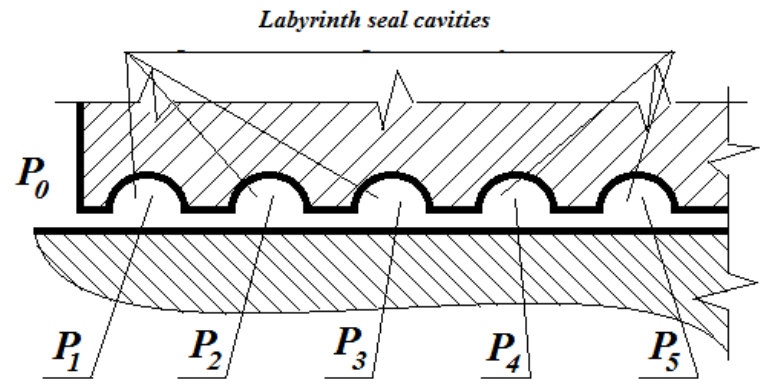

Figure 6. Sketch design of labyrinth seal

The decrease in the output dynamic pressure P0 in the above design of the labyrinth seal is incremental by increasing the working volume of the gap in the cavities (cells) of the maze. That is, $\mathrm{P} 0>\mathrm{P} 1>\mathrm{P} 2>\ldots>\mathrm{Pn}$ ( $\mathrm{Pi}$ is the pressure in the cavities (cells) of the maze, $\mathrm{n}$ is the number of cavities of the maze). ${ }^{6}$

There was developed a hypothesis, which is based on the above analysis of the processes of migration of pollutants in the NTGEs and the structural features of forest gas-dust lane roads. It envisages the creation of artificial lacunar cavities in the structure of the forest gas-dust lane of the highway. This should reduce the aerodynamic pressure of turbulent

\footnotetext{
${ }^{6}$ Шелудченко Л.С., Поліщук Д.В. Екологічна оцінка шумового забруднення міста, спричиненого діяльністю автотранспортних засобів і стаціонарних джерел. Екологічні науки: науково-практичний журнал № 4(23). Київ : Державна екологічна академія післядипломної освіти та управління, 2018. C. 10-14. DOI:https//doi.org/10.32846/2306-9716-2018-4-23-2; Овчарук О.В., Шелудченко Л.С., Гуцол Т.Д. Экологическая характеристика конструкций газопылезащитных лесополос». European Journal of Intelligent Transportation Systems 1(1), November 2018/ P. 7-14. DOI: https//doi.org/10.31435/ rsglobal_ejits/30112018/6216.
} 
air streams of polluting aerosols. Because it leads to accelerated deposition processes of mineral contaminants within the lacunar cavities (phytocenotic niches) and, as a consequence, to the intensification of deposition of dust pollutants. On the basis of the obtained results, the ecologically rational parameters of artificially created phytocenotic niches (lacunar cavities) in the construction of forest gas-dust lanes of motorways of categories 1a, 1b, 2 and 3 are substantiated, which allows to increase their functional efficiency by indicators. Table 1). Thus, the dispersed particles of dust aerosols with fractions of dispersed particles> $150 \mu \mathrm{m}$ are completely deposited by the forest belt. And the proportion of undoped dust of smaller fractions $(<150 \mu \mathrm{m})$ does not exceed $0,12 \%$ of the total mass of dust dispersed in the air aerosol and practically does not depend on the season. The volume of migration of heavy metals beyond the limits of the lane of the highway does not exceed $\sim 4 \%$. At the same time, the share of oxygen recovered by the massif of shrubs and forests of forest gas-dust protection strip, in the presence of lacunar cavities (phytocenotic niches), is $45 \ldots 51 \%$ in summer and $28 \ldots 50 \%$ in winter. $^{7}$

Table 1

\section{Structure models of forest gas-dust lane}

for highways of categories 1a, 1b, 2, 3, 4, 5

\begin{tabular}{|c|c|}
\hline $\begin{array}{l}\text { Category of } \\
\text { highway }\end{array}$ & The design model of forest gas-dust protection strip \\
\hline $\begin{array}{l}\text { Forest gas-dust } \\
\text { lane roads of } \\
\text { categories I-a, } \\
\text { I-b (the rows of } \\
\text { planting }-17 \text { ) }\end{array}$ & 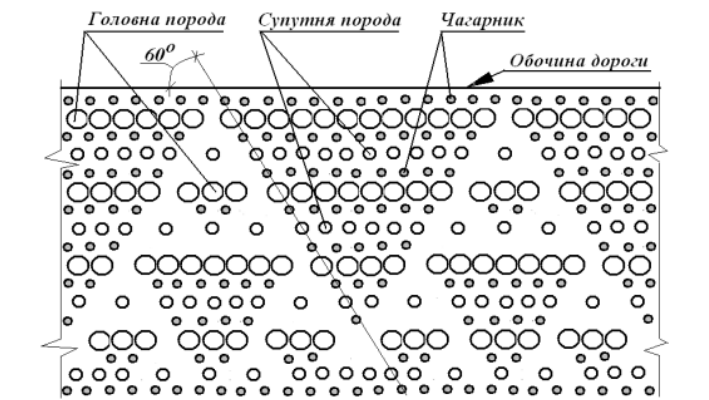 \\
\hline
\end{tabular}

7 Sheludchenko L., Voznyuk S. The results of analytical investigation of aerodynamic properties forest gas-dust proof ing strips with artificially created lacunar cavities. Scientific journal "Ecological safety”. Kremenchuk : KrNU, 2016. Number 1/2016(21). P. 81-84. 


\begin{tabular}{|c|c|}
\hline $\begin{array}{l}\text { Forest gas-dust } \\
\text { lane roads of } \\
\text { category II } \\
\text { (the rows of } \\
\text { planting - 13) }\end{array}$ & 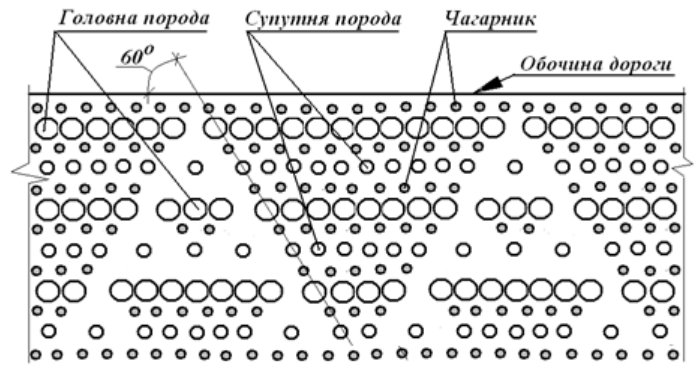 \\
\hline $\begin{array}{l}\text { Forest gas-dust } \\
\text { lane roads of } \\
\text { category III } \\
\text { (the rows of } \\
\text { planting -9) }\end{array}$ & 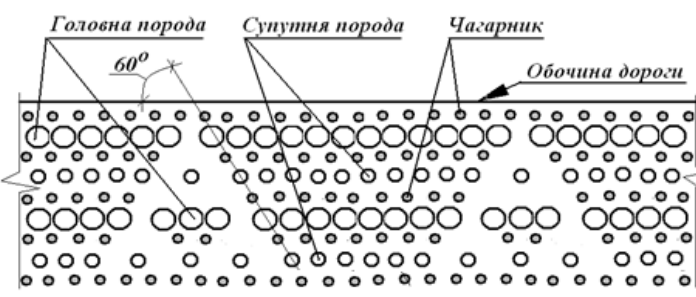 \\
\hline $\begin{array}{l}\text { Forest gas-dust } \\
\text { lane roads of } \\
\text { category IV } \\
\text { (the rows of } \\
\text { planting }-5 \text { ) }\end{array}$ & 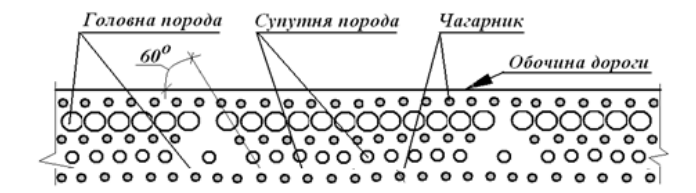 \\
\hline $\begin{array}{l}\text { Forest gas-dust } \\
\text { lane roads of } \\
\text { category V } \\
\text { (the rows of } \\
\text { planting }-3 \text { ) }\end{array}$ & $\overbrace{\circ \circ}^{\text {Головна порода }}$ \\
\hline
\end{tabular}

\section{Estimation results of deposition intensity of dust pollutants in lacunar cavities of the protective forest belt by the index of carbon black (free carbon) and lead compounds accumulation in soil}

Results of indirect estimation of mass distribution and nature of deposition of dust pollutants in artificially created phytocenotic niches according to the cross-section profile (sampling scheme is shown in Fig. 7) of forest gas-dust lane of category 2 highway (in terms of traffic intensity) carbon black (free carbon) are shown in table 2. 


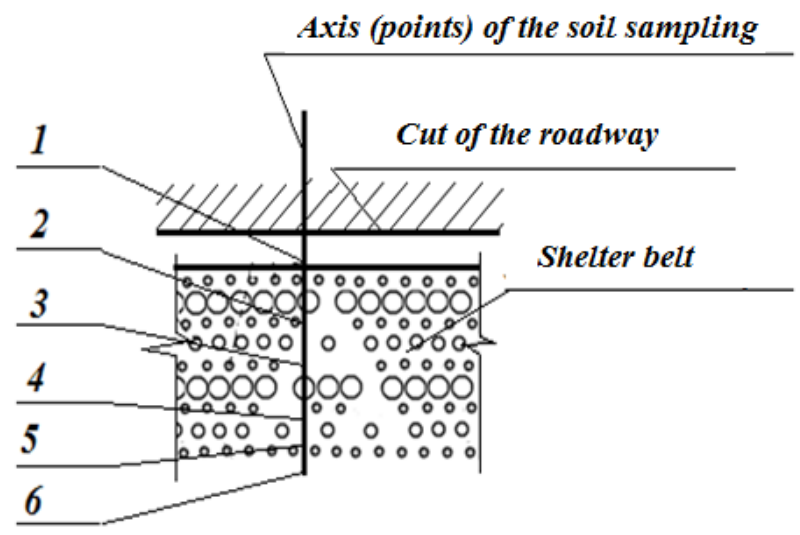

Figure 7. Scheme of soil sampling in the horizontal plane tree-shrub planting of forest gas-dust protection strip in planting rows and in phytocenotic niches

Table 2

Mass distribution of the of deposited carbon by the cross-section profile of the construction of category 3 forest gas-dust lane (average data)

\begin{tabular}{|c|c|c|}
\hline $\begin{array}{c}\text { Sampling } \\
\text { point number }\end{array}$ & $\begin{array}{c}\text { Weighing bottles } \\
\text { number }\end{array}$ & $\begin{array}{c}\text { Carbon content, } \\
\mathbf{~ m g ~ / ~ k g ~}\end{array}$ \\
\hline 1 & 148 & 26,6 \\
\hline 2 & 249 & 24,2 \\
\hline 3 & 174 & 27,2 \\
\hline 4 & 176 & 31,2 \\
\hline 5 & 167 & 28,2 \\
\hline 6 & 145 & 17,6 \\
\hline
\end{tabular}

There was determined the carbon content at individual points of the soil cover of the cross section of the forest gas-dust protection strip. According to the results we determined the topographic nature of the distribution of the deposition of dust emissions (soot) by the transport complex (motor transport stream) by structural features of the shrub planting (Fig. 8). 


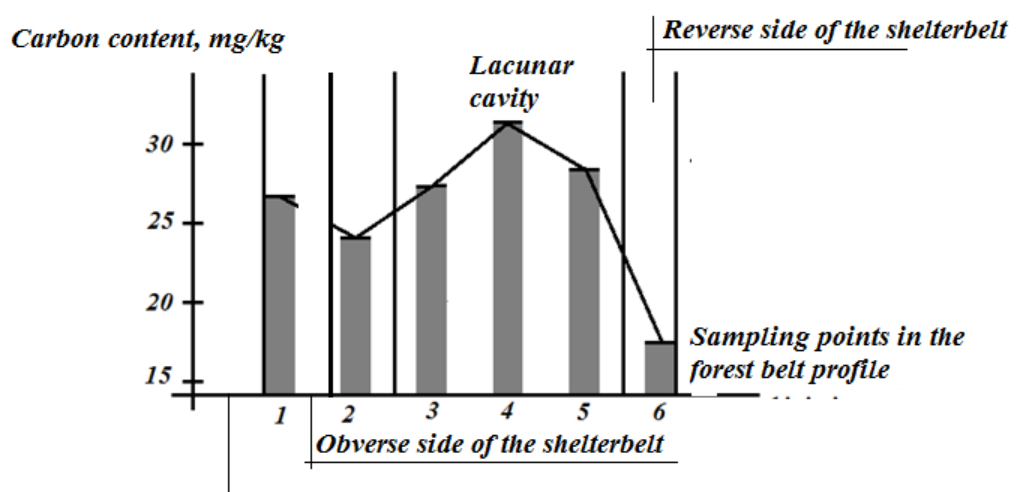

Highway side area

\section{Fig. 8. The nature of the volume distribution and the intensity of the depositdust emissions (by mass of carbon deposited) in the cross-section profile of the forest gas and dust lanes}

The nature of the distribution of free carbon (soot) on the profile of the cross section of the forest gas-dustproof strip (for the construction of forest lane category 3) clearly determines the intensification of the process of deposition of dust contaminants of the motor transport complex within the artificially created lacunar. It is established that $\sim 17 \%$ of the total dust emissions are deposited on the obverse side of the protective forest strip (the area of the roadside of the total width of the highway); and the share of dust emissions in the soil within the lacunar cavity is $\sim 57 \%$, whilst the whole -bush planting of the forest belt is deposited only $\sim 26 \%$, which is almost 2,2 times less. At the same time, it is determined the level of protection of the roadside territory of the category 3 motorway lane. There should be counted a forest gas-dust band of typical construction with artificially created lacunar cavities (phytocenotic niches), not lower (by the mass distribution of free carbon) by $90 \pm 3 \%$.

Similar results, regarding the deposition nature of dust emissions of the motor transport complex by the forest gas-dust lane array for the investigated section of the category 3 highway, were obtained on the results basis of the experimental determination of the heavy metals distribution (for example $\mathrm{Pb}$ ) in the forest belt soil (Table 3). According to the results of the lead content determination at individual points of the soil cover of the cross section profile in the forest gas-dust protection 
strip, there was determined the topographic nature of the distribution of dust emissions (heavy metals) by the motor transport complex according to structural features of the tree (shrubs) planting (Fig. 9).

Table 3

Lead mass distribution by cross-sectional profile of a category 3 forest gas-dust lane (average data)

\begin{tabular}{|c|c|c|}
\hline $\begin{array}{c}\text { Sampling point } \\
\text { number }\end{array}$ & $\begin{array}{c}\text { weighing bottles } \\
\text { number }\end{array}$ & $\begin{array}{c}\text { Lead content, } \\
\mathbf{m g} / \mathbf{~ k g}\end{array}$ \\
\hline 1 & 148 & 54,2 \\
\hline 2 & 249 & 14,7 \\
\hline 3 & 174 & 39,6 \\
\hline 4 & 176 & 51,8 \\
\hline 5 & 167 & 12,4 \\
\hline 6 & 145 & 7,1 \\
\hline
\end{tabular}

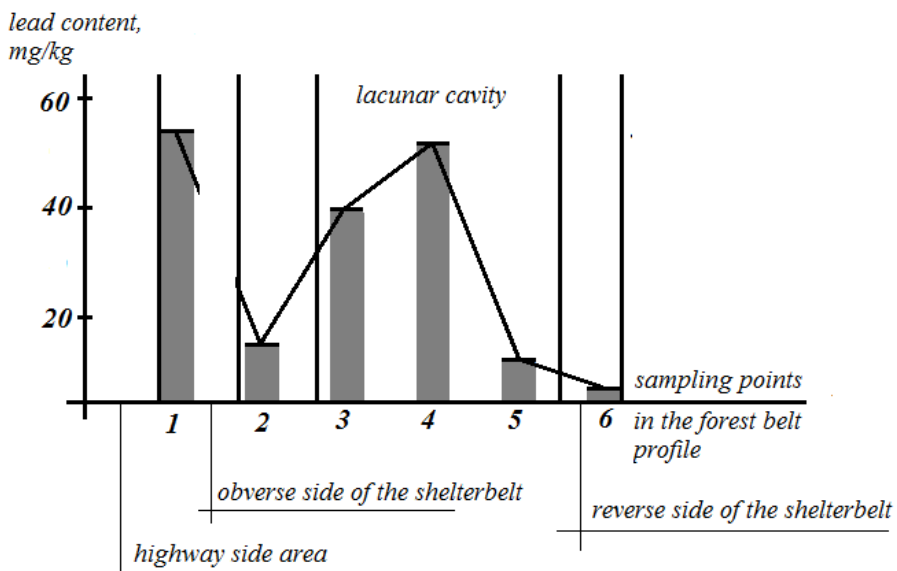

Fig. 9. The nature of the volume distribution and the intensity of the deposit dust emissions (by mass of lead deposited) in the cross-section profile of the forest gas and dust lanes

It is established that a sufficiently large proportion $(\sim 30 \%)$ of total lead emissions is deposited in the roadside of the highway adjacent to the obverse side of the forest gas-dust lane. Therefore, to analyze the nature of heavy metals distribution in the wood-shrub massif for $100 \%$ of total emissions is the total amount of lead compounds detected in soil samples taken at sampling points (Fig. 7) - 2, 3, 6 . 
The analysis results of the specific content of lead compounds in the soil profile of the cross section of the protective forest belt (by the nature of the particle distribution from the total emissions of motor traffic) are largely identical to the results in the distribution of dust pollutants in the soil by the coal content.

Thus, in the lacunar zone is concentrated $\sim 83 \%$ of total lead compounds. They are deposited within the shrubs of the gas-dustprotective forest belt (58\% of total emissions). In this case, the experimentally determined share of dust emissions (by lead compounds) on the reverse side of the shelterbelt does not exceed $\sim 4 \%$. It determines the level of protection of the adjacent territory of the category 3 highway, in the presence of a forest gas-dust lane of a typical structure with artificially created lacunar cavities (phytocenotic niches), not worse than $96 \pm 3 \%$.

Thus, it is experimentally proved that artificially created lacunar cavities (phytocenotic niches) in arrays of wood-shrubs plantations of forest gas-dust lane of highways provide higher levels of protection for the areas adjacent to the highway strip from dust emissions produced by traffic flows. It is established that up to $60 \%$ of the total dust emissions are deposited in the area of the lacunar cavities of the forest belt. The forest band gradient varies from 90 to $96 \pm 3 \%$ in terms of the dispersed phase concentration in the air streams of dust aerosols.

\section{CONCLUSIONS}

This work focuses on solving the current scientific and practical problem of developing a protection system of roadside landscapes from the adverse effects of pollutants, which are the source of vehicle flows.

To ensure a sufficient level of ecological safety of the territory, there have been developed structures of gas-dust protective strips of woodshrub type. Their parameters considered all the necessary factors: the category of the highway, the intensity of the traffic flow, the climatic and landscape features of the territory.

One of the most effective measures for maintaining the ecological balance of natural-technogenic geo-ecosystems with a developed road

${ }^{8}$ Ivanyshyn V., Sheludchenko L., Hutsol T., Rud A., Skorobogatov D. Mass transfer management and deposition of contaminants within car road zones. Environment. Technology. Resources. Proceedings of the 12th International Scientific and Practical Conference / Volume 1. Rezekne Academy of Technologies, (2019). Р. 70-74.; Шелудченко Л.С. Функціональні ознаки автотранспортного комплексу. «Автомобіль і електроніка сучасні технологї» Електронне наукове фахове видання, 13/2018, ХНАДУ, Харків, 2018. С. 75-80. DOI: 10.30977/VEIT.2018.13.0.75. 
transport network is the creation of artificial linear-double-sided geochemical barriers in the form of forest gas-dust-protective strips of tree-shrub type. Their planting structure includes a maze phytocoenotic niches (artificially created lacunar cavities) to limit the migration of dust mineral contaminants beyond the confines of the highway.

It has been determined that the level of deposition of dust mineral contaminants produced by motor transport streams, forest gas-dusty strips of woody-shrub type with artificially created labyrinth of cavities is not less than $66 \%$ in the winter period and reaches $99 \%$ in the summer. In this case, the dispersed particles of dust pollutants with fractions $>150$ $\mu \mathrm{m}$ are completely deposited in the forest belt. The fraction of nondeposited dust of smaller fractions $(<15 \mu \mathrm{m})$ does not exceed $0.12 \%$ of the total mass of dust dispersed in the air aerosol and is practically independent of the season.

It is established that the dust-protective properties of forest gas-dustlane roads, including lacunar cavities in their structure, increase from 66$72 \%$ for the construction of the forest lane of category 3 to $99 \%$ for the construction of forest lane categories $1 \mathrm{a}, 1 \mathrm{~b}$. In this case, the increase in the gradient of $I$ forest strips from 0.03 to 0.24 (in summer) and from 0.03 to 0.31 (in winter) with increasing number of phytocenotic niches in the structure of tree-shrub planting of the strip from 3 to 6 indicates their functional effectiveness in protecting the roadside landscapes from dust emissions from traffic flows.

\section{SUMMARY}

In the dissertation have been established that an effective measure for implementation ecological safety of natural-technogenic geoecosystem with a developed road network is the creation of an artificial linearlybilateral geochemical barriers in the form of a forest gas-dustproofing strips of wood-shrub type, which in structure is provided the maze of phytocenotic niches (artificially created lacunar cavities). Has proved ecological and landscape characteristics of structures lacunar cavities, signs of which should be fractal-invariant to all forest strip and causing the filtering of dust aerosols produced by traffic flows, that ensures intensification the deposition processes of mineral contaminants by massif of the protective forest strip within the abduction's strip of the highway (by an indicator of mass the dispersed phase aerosol) $>66 \%$ in winter and $99 \%$ in summer. Designed a number of structures forest gasdustproofing strips with the maze of lacunar cavities by road categories $1 \mathrm{a}, 1 \mathrm{~b}, 2$ and 3 provide increase their dustproofing properties on indicators of functional efficiency is $\sim 70 \%$ for construction of the road's 
strip by category 3, 98\% by category 2 and by category $1 \mathrm{a}$ and $1 b>99 \%$ (by weight of dust pollutants).

\section{REFERENCES}

1. Шмандій B.M., Шелудченко Л.С., До питання забезпечення екологічної безпеки територій 3 розвиненою інфраструктурою автодорожньої мережі. Збірник наукових працььVII-й Всеукраӥнського з'їзу екологів з міжнародною участю. Вінниця : ВНТУ, 2019. С. 26.

2. Шелудченко Л.С., Замойський С.M. Управління екологічною безпекою в умовах функціонування автодорожньої мережі. Збірник наукових праць XVII Міжнародної науково-технічної конферениії «Проблеми екологічної безпеки». Кременчук : КрНУ, 2019. С. 92-96.

3. Внукова Н.В. Вплив автомобільних доріг на екобезпеку комплексу «автомобіль-дорога-середовище». Eastern-European Journal of Enterprise Technologies 5 (3(53)), 2011. C. 43-46.

4. Гриценко А.В., Соловей В.В., Внукова Н.В. Ризики техногенно-екологічного характеру при експлуатації об'єктів автотранспортної інфраструктури. Экология и промышленность. 3. 2011. C. 37-40.

5. Внукова Н.В., Желновач Г.М. Вибір екологічно значимих параметрів автотранспортних систем для оцінки екологічної небезпеки придорожнього простору. Науковий журнал «Екологічна безпека» . Кременчук : КрНУ, 2011 № 2/2011(12). С. 119-123.

6. Шелудченко Л.С. Розроблення конструкцій газо-пилозахисних лісосмуг автодорожньої мережі. Кам'янець-Подільський : В-во ПДАТУ, 2015. 134 с.

7. Патент України № 56323, МПК Е01F15/00 Лісова газопилозахисна смуга автомобільної дороги / Л.С. Васик, М.І. Бахмат, Б.А. Шелудченко, О.М. Бахмат, І.А. Шелудченко (Україна). u201007589; заявлено 10.06.2010; опубл. 10.01.2011, Бюл. №1.

8. Шелудченко Л.С. Екологічна безпека ландшафтів природнотериторіальних комплексів, які трансформовано автотранспортними мережами. Науковий журнал «Екологічна безпека». Кременчук : КрНУ, 2017 № 2/2017(24). С. 9-13.

9. Шелудченко Л.С., Шелудченко Б.А., Вознюк С.В. Аналітичне обгрунтування параметрів лакунарності лісових газо-пилозахисних смуг автомобільних доріг. Наук.-техн. журнал «Екологічна безпека та збалансоване ресурсокористування». Спец. вип. ІФНТУНГ, Івано-Франківськ, 2014. С. 56-60.

10. Шелудченко Л.С., Поліщук Д.В. Екологічна оцінка шумового забруднення міста, спричиненого діяльністю автотранспортних засобів i стаціонарних джерел. Екологічні науки: науково- 
практичний журнал № 4 (23). Київ : Державна екологічна академія післядипломної освіти та управління, 2018. С. 10-14. DOI : https//doi.org/10.32846/2306-9716-2018-4-23-2.

11. Овчарук О.В., Шелудченко Л.С., Гуцол Т.Д. Экологическая характеристика конструкций газо-пылезащитных лесополос автомобильных дорог». European Journal of Intelligent Transportation Systems 1(1), November 2018/ P. 7-14. DOI : https//doi.org/10.31435/rsglobal_ejits/30112018/6216.

12. Sheludchenko L., Voznyuk S. The results of analytical investigation of aerodynamic properties forest gas-dustproofings trips with artificially created lacunar cavities. Scientific journal "Ecological safety”. Kremenchuk : KrNU, 2016. Number 1/2016(21). P. 81-84

13. Ivanyshyn V., Sheludchenko L., Hutsol T., Rud A., Skorobogatov D. Mass transfer management and deposition of contaminants within car road zones. Environment. Technology. Resources. Proceedings of the $12^{\text {th }}$ International Scientific and Practical Conference / Volume 1. Rezekne Academy of Technologies, (2019). P. 70-74.

14. Шелудченко Л.С. Функціональні ознаки автотранспортного комплексу. "Автомобіль $i$ електроніка сучасні технологіï» Електронне наукове фахове видання, 13/2018, ХНАДУ, Харків, 2018. C. 75-80. DOI: 10.30977/VEIT.2018.13.0.75.

\section{Information about authors:} Sheludchenko L. S.,

Candidate of Technical Sciences, Associate Professor of Department of Transport Technologies State Agrarian and Engineering University in Podilia 13, Shevchenko St., Kamyanets-Podilsky, Khmelnytsky region, 32300, Ukraine

Semenyshena R. V., Candidate of Pedagogical Sciences, Assistant of the Department of General Technical Disciplines State Agrarian and Engineering University in Podilia 13, Shevchenko St., Kamyanets-Podilsky, Khmelnytsky region, 32300, Ukraine 